\title{
Effect of l-glutamine on myenteric neuron and of the mucous of the ileum of diabetic rats
}

\author{
ELEANDRO A. TRONCHINI ${ }^{1}$, ALINE R. TREVIZAN ${ }^{1}$, $^{\text {CRISTIANO M. TASHIMA }}{ }^{1}$, PRISCILA DE FREITAS $^{1}$, \\ ROBERTO B. BAZOTTE ${ }^{2}$, MARLI A.S. PEREIRA ${ }^{1}$ and JACQUELINE N. ZANONI ${ }^{1}$ \\ ${ }^{1}$ Departamento de Ciências Morfológicas, Universidade Estadual de Maringá, \\ Av. Colombo, 5790, 87020-900 Maringá, PR, Brasil \\ ${ }^{2}$ Departamento de Farmácia e Farmacologia, Universidade Estadual de Maringá, \\ Av. Colombo, 5790, 87020-900 Maringá, PR, Brasil \\ Manuscript received on May 17, 2012; accepted for publication on March 15, 2013
}

\begin{abstract}
The objective of this work was to investigate the effect of the L-glutamine supplementation to prevent - diabetes induced changes in myenteric neurons and also to verify the effect on the mucosa of the ileum of Wistar rats. The animals were divided in five groups $(n=5)$ : untreated normoglycaemic (UN), normoglycaemic treated with L-glutamine (NG), untreated diabetics (UD), diabetics treated with L-glutamine, starting on the $4^{\text {th }}$ (DG4) or $45^{\text {th }}$ day following diabetes induction (DG45). The amino acid was added to the diet at $1 \%$. The density and size of neurons, the metaphasic index in the crypt, the height of the villus, the depth of the crypt and the number of globet cells were determined. There was no difference in the neuronal density and in the cellular body area of the myosin-stained myenteric neurons of groups DG4 and DG45 when compared to group D. The metaphase index and the number of goblet cells showed no significant differences when all groups were compared $(\mathrm{P}>0.05)$. The villi height of groups DG4 and DG45 were $45.5 \%(\mathrm{P}<0.05)$ and $32.4 \%(\mathrm{P}>0.05)$ higher than those in group UD, respectively. The analyzed crypts showed similar depth for all studied groups.
\end{abstract}

Key words: diabetes mellitus, L-glutamine, myenteric plexus, myosin- $\mathrm{V}$, rats.

\section{INTRODUCTION}

Diabetes mellitus is a heterogeneous clinical syndrome characterized by endocrine-metabolic abnormalities that alter homeostasis. The neurological manifestations are probably the most common among the chronic complications caused by diabetes mellitus. Diabetic neuropathy is a heterogeneous group of disorders, with an extensive range of abnormalities (Vinik and Mehrabyan

Correspondence to: Jacqueline Nelisis Zanoni

E-mail: jnzanoni@uem.br
2004), that can affect the peripheral nervous system harming the quality of life of individuals (Vinik 1999, Afzaal and Saleem 2002).

Many studies have demonstrated alterations in the myenteric plexus of several intestinal segments of diabetic rats, not just regarding the reduction on the number, but also on the size of neurons (Belai et al. 1988, 1991, Belai and Burnstock 1990, Zanoni et al. 1997, 2003). An important factor related to the diabetic neuropathy is oxidative stress (Vinson et al. 1989, Baynes 1991), which happens when 
there is an increase of reactive oxygen species (ROS) (Parthiban et al. 1995, Kuyvenhoven and Meinders 1999) and/or a reduction on the efficiency of the endogenous antioxidants (Baynes 1991, Kuyvenhoven and Meinders 1999).

Another factor that provokes neuronal degeneration is the intracellular increase of sorbitol and fructose, due to the increase of the aldose reductase enzyme activity in the polyol metabolic pathway as a consequence of hyperglycemia (Vinik 1999, Giugliano et al. 1996, Afzaal and Saleem 2002). As the glucose conversion by aldose reductase into sorbitol consumes NADPH, there is a reduction on the ratio NADPH:NADP ${ }^{+}$(Giugliano et al. 1996). That reduction can impair the reactions that NADPH need, especially the oxidized glutathione conversion to reduced glutathione by the glutathione reductase. Consequently, reduced levels of glutathione is observed in diabetes mellitus, which increases the susceptibility of cells to oxidative stress (Vincent et al. 2004). Hence, measures that increase the availability of antioxidants may be relevant in the treatment of the chronic complications associated with diabetes mellitus. Within this context, the L-glutamine supplementation is likely to present some neuroprotective effects, since it is a substrate for the production of glutathione (Amores-Sánchez and Medina 1999).

L-glutamine is a non essential amino acid, stored mainly in the skeletal muscle (75\%) and in the liver (25\%). Among its multiple functions, L-glutamine serves as primary carrier of nitrogen among the tissues and it is the main source of energy for the speed proliferation of cells, such as the intestinal epithelium (Vahdat 2001). L-glutamine is metabolized through the phosphate-L-glutaminase, resulting in glutamate and ammonia. Glutamate is transported to the cytosol and it can be used in the synthesis of glutathione (Amores-Sánches and Medina 1999), thus, maintaining the glutathione concentration in the cells. The absence of L-glutamine compromises nitrogen transport, causes a depletion of energy and a reduction on the glutathione levels (Wolfgand et al. 2003). According to Watford et al. (1984), there is a reduction of the plasmatic L-glutamine during diabetes mellitus. Therefore, it is possible that glutamine may help to keep the integrity of the intestinal mucosa in diabetes mellitus.

The objective of this work was to evaluate the effect of the L-glutamine supplementation on myosin-V-stained myenteric neurons and on the mucosa in the ileum of streptozotocin-induced diabetic rats.

\section{MATERIALS AND METHODS}

Procedure WITH THE ANIMALS

All of the experiments described in this work were supervised and approved by the Committee of Ethics on Animal Experimentation of the Universidade Estadual de Maringá. Twenty-five male Wistar rats (Rattus norvegicus), 90 days of age were used. Diabetes was induced through the intravenous administration of $35 \mathrm{mg} \cdot \mathrm{kg}^{-1}$ of body weight of streptozotocin (Sigma, St. Louis,USA), dissolved in a buffer solution of $10 \mathrm{mmol} . \mathrm{L}^{-1}(\mathrm{pH}$ $4.5)$, prior to a 14-hour-fast. The injection with streptozotocin resulted in the diabetic syndrome with polyuria, polyphagia and polydipsia. The glycaemia (Bergmeyer and Bernet 1974) of each animal was assessed on the $4^{\text {th }}$ day after the diabetes onset, with a mean value of $486.9 \pm 14.25$ mg.dL ${ }^{-1}$. The rats were divided in five groups: untreated normoglycaemic (UN), normoglycaemic treated with L-glutamine (NG), untreated diabetics (UD), diabetics treated with L-glutamine, starting on the $4^{\text {th }}$ (DG4) or $45^{\text {th }}$ day following the onset of diabetes (DG45). The amount of food intake, water consumption and eliminated urine were assessed for five days of the last week of every month, with use of metabolic cages.

The animals were kept in individual cages, receiving water and food (Nuvital ${ }^{\circledR}$ lab) ad libitum, with a 
photoperiod ( $6 \mathrm{am}-6 \mathrm{pm}$ ) and controlled room temperature $\left(24^{\circ} \mathrm{C} \pm 2^{\circ} \mathrm{C}\right)$. Some animals were fed chow supplemented with L-glutamine (1\%) (Ajinomoto, Tokyo, Japan), which was prepared weekly.

On the $210^{\text {th }}$ day, the animals were anesthetized with sodium thiopental (40 mg. $\mathrm{kg}^{-1}$ of body weight) and their blood collected by heart puncture to measure the glucose (Bergmeyer and Bernet 1974).

\section{Neuronal Counting AND Morphometric ANALysis of}

\section{MYENTERIC NEURONS}

The rats were perfused with $250 \mathrm{~mL}$ of fixing solution containing sodium periodate $(10 \mathrm{mM})$, lysine $(75 \mathrm{mM})$, paraformaldehyde $(1 \%)$ in phosphate buffer (PB), pH 7.4 (37 mM) followed by a $1.1 \%$ saline solution. After perfusion, each ileum was removed, rinsed with saline solution, opened and immersed for 1 hour in the same fixing solution. Subsequently, the segments were dehydrated in ethanol $(50,70,80,90$, and $100 \%)$, remaining in each solution for $10 \mathrm{~min}$, cleared in xylol (10 min), rehydrated with $100,95,90,80,70 \%$ ethanol, and stored in $70 \%$ ethanol. Afterwards, the segments were dissected under a stereomicroscope with transillumination, to remove the mucous and submucous layer, obtaining whole mount external muscle layers preparations. The neurons were stained for immunoreactivity to myosin V (Drengk et al. 2000) as described previously using an antibody developed in the laboratories of Cellular and Molecular Biology Department, Universidade de São Paulo (USP), Ribeirão Preto. These preparations were rinsed twice in phosphate-buffered saline (PBS) $0.1 \mathrm{M}, \mathrm{pH} 7.4$ and blocked with PBS, bovine serum albumin (BSA) (2\%) (Sigma, St Louis, MO, USA), goat serum (2\%), Triton-X-100 (0.5\%) (Sigma, St Louis, MO, USA) at room temperature (RT). Then, the segments were incubated in a solution containing a 1:750 diluition of the rabbit serum containing the anti-myosin- $\mathrm{V}$ antibody in PBS, BSA (2\%), Triton-X-100 (0.1\%) and normal goat serum (2\%) at RT for $24 \mathrm{~h}$. After incubation, the tissues were rinsed twice in PBS Triton-X-100 (0.1\%) and twice in the solution of PBS + Tween $0.05 \%$ (Sigma, St Louis, MO, USA). Segments were incubated in secondary antibodies (anti rabbit) conjugated with peroxidase 1:1,000 (Pierce, Rockford, USA) at RT, by shaking for $24 \mathrm{~h}$. They were then rinsed $4 \times 15$ min, in PBS with $0.05 \%$ Tween-20. The tissues were developed with diaminobenzidine (DAB) (Sigma, St Louis, MO, USA) and mounted in glycerol gel. The negative control was performed with the lack of primary antibody.

Enteric neurons were counted using a BX 40 Olympus microscope with a 40x objective. Quantitative analysis was performed at the intermediate region $\left(60^{\circ}-120^{\circ} ; 240^{\circ}-300^{\circ}\right.$, with $0^{\circ}$ as the mesenteric insertion) (Zanoni et al. 2005). Sixty microscope fields were randomly counted for each preparation. The area of each microscopic field was $0.229 \mathrm{~mm}^{2}$. The results were shown in cells.cm².

For morphometric analysis of the myenteric neurons, images were taken with a high-resolution camera and sent to a microcomputer. The cell profile $\left(\mu \mathrm{m}^{2}\right)$ of 100 cell bodies for each animal was measured through the image-analyses software Image-Pro-Plus 4, in a total of 500 neurons for each studied group. Neurons were classified by size into $100 \mu \mathrm{m} 2$ bins and the percentage of each group was calculated for each bin.

HistologicAl PROCEDURE

\section{Metaphasic index}

Two hours prior the sacrifice, the animals were injected with $1 \mathrm{mg} . \mathrm{Kg}^{-1}$ vincristine sulfate (Oncovin ${ }^{\circledR}$, Eli Lilly, Brazil), a blocking agent of the mitotic spindle. The injections were always given at the same time of day to avoid circadian variations. Soon afterwards, the ileum was collected and carefully washed to remove the feces. The segments were opened along the mesenteric border, fixed with pins into a paper card with the 
mucosa surface upward. They were then immersed in buffered formalin for 6 hours.

After fixation, the ileum was dehydrated and embedded in 2-hydroxyethyl-metacrilate (Leica Historesine - Embedding Kit, Germany). Two micrometer semi-serial sections were made in a Leica RM 2145 microtome, with glass razor. The sectioned resins were stained by hematoxylin-eosin (HE).

The metaphasic index was calculated by counting the interphasic and metaphasic epithelial nuclei in the ileum crypts. Approximately 2,500 cells per animal were counted on BX 40 Olympus microscope under a $40 \mathrm{X}$ lens. The metaphasic index was expressed as the percentage of nuclei in metaphase divided by the overall number of counted nuclei.

\section{Goblet cells in the villus}

Resins sectioned were stained using the pricroindigo-carmin/periodic acid Schiff (PAS) histochemical technique to stain goblet cells. The number of stained goblet cells in one side of the villus and the picro-indigo-carmim/periodic acid-Schiff (PAS) method in one side of the villus and the overall number of cells on the same side of the villus were counted in all rats of each group. Approximately 2,500 cells per animal were counted - including positive or negative PAS - in longitudinal sections of intact villus (Hernandes et al. 2003) using BX 40 Olympus microscope under a 40 X lens. The number of goblet cells was expressed as the percentage of PAS-stained goblet cells divided by the overall number of counted cells.

\section{Morphometry of villus and crypts}

The height of the villus and the depth of the crypts were measured in well-guided longitudinal sections. The crypts depth measured as the distance between the junction crypt-villi and the crypt base. The length of the villus is measured as the distance between the crypt-villus junction and the villus apex. The morphometric assessment was carried out on 30 villus and 30 crypts per animal (150 measurements per group) using a 10x objective and an ocular with Zeiss micrometer grade.

\section{Statistical analysis}

The data were analyzed by the minimum squares method, through the Variance Analysis (ANOVA), followed by Tukey test, which was used as a posttest to compare the means. Since the areas of the cell bodies did not present a similar distribution, we employed the Variance Analysis and t-test to compare the means. The analyses were carried out with the software Prisma 3.0. The results are shown as means \pm standard error $(\mathrm{M} \pm \mathrm{SE})$.

\section{RESULTS}

PROCEDURES ANIMALS

We verified in this study that the diabetic rats (groups UD, DG4 and DG45) did not gain weight in the same proportion as the animals from the normoglycaemic groups (UN and NG) $(\mathrm{P}<0.05)$ (Table I). The L-glutamine supplementation did not alter the final body weight of rats from groups DG4 and DG45 when compared to the animals from group UD $(\mathrm{P}>0.05)$ (Table I). The diabetic condition was kept throughout the studied period, since glycaemia levels were high in all of the investigated diabetic groups. The diabetic syndrome was also verified by the polyphagia, polyuria, polydipsia and the L-glutamine supplementation did not alter these parameters (Table I).

\section{MYENTERIC NEURONS}

The myosin-V technique allowed us to observe the three components of the myenteric plexus (Fig. 1). The primary plexus was well evidenced, with the presence of ganglia and interganglionic nerve fibers. Isolated neurons were observed in the path of the nerve fibers of the primary plexus. The secondary and tertiary plexuses were also quite 
TABLE I

Glycaemia (GI), initial and final body weight (IBW and FBW), daily water consumption (DWC), daily food intake (DFI) and daily urine excretion (DUE) for animals belonging to the following groups: untreated normoglycaemic (UN), glutamine-treated normoglycaemic (NG), untreated diabetic (UD), glutamine-treated diabetic (DG4), glutamine-treated diabetic (DG45). All results are shown as means \pm SE. $n=5$ rats per group.

\begin{tabular}{|c|c|c|c|c|c|}
\hline Parameters & $\mathbf{U N}$ & NG & UD & DG4 & DG45 \\
\hline${\mathrm{GI} \mathrm{mg} \cdot \mathrm{dl}^{-1}}^{-1}$ & $158.1 \pm 9.3^{\mathrm{a}}$ & $143.2 \pm 7.1^{\mathrm{a}}$ & $649.6 \pm 36.5^{b}$ & $524.7 \pm 44.8^{\mathrm{c}}$ & $500.5 \pm 28.4^{\mathrm{c}}$ \\
\hline IBW.g ${ }^{-1}$ & $330.6 \pm 8.5^{\mathrm{a}}$ & $300.3 \pm 9.3^{\mathrm{a}}$ & $314.8 \pm 9.2^{\mathrm{a}}$ & $328.0 \pm 8.2^{\mathrm{a}}$ & $312.4 \pm 9.0^{\mathrm{a}}$ \\
\hline FBW.g ${ }^{-1}$ & $480.3 \pm 10.7^{\mathrm{a}}$ & $406.4 \pm 13.4^{\mathrm{b}}$ & $309.3 \pm 17.7^{\mathrm{c}}$ & $292.1 \pm 10.9^{c}$ & $286.7 \pm 18.5^{\mathrm{c}}$ \\
\hline DWC.ml ${ }^{-1}$ & $54.35 \pm 2.6^{\mathrm{a}}$ & $49.2 \pm 1.35^{\mathrm{a}}$ & $185.7 \pm 11.7^{\mathrm{b}}$ & $213.3 \pm 7.0^{\mathrm{b}}$ & $160.6 \pm 5.0^{\mathrm{b}}$ \\
\hline DFI. $g^{-1}$ & $32.1 \pm 0.75^{\mathrm{a}}$ & $28.77 \pm 1.1^{\mathrm{a}}$ & $50.8 \pm 2.1^{\mathrm{b}}$ & $54.82 \pm 1.2^{\mathrm{b}}$ & $48.3 \pm 2.5^{\mathrm{b}}$ \\
\hline DUE.ml ${ }^{-1}$ & $12.82 \pm 1.7^{\mathrm{a}}$ & $10.7 \pm 1.6^{\mathrm{a}}$ & $101.7 \pm 5.5^{b}$ & $127 \pm 7.0^{\mathrm{c}}$ & $88.7 \pm 3.8^{\mathrm{b}}$ \\
\hline
\end{tabular}

Means followed by different letter on the same line are different by the test of Tukey $(\mathrm{P}<0.05)$.
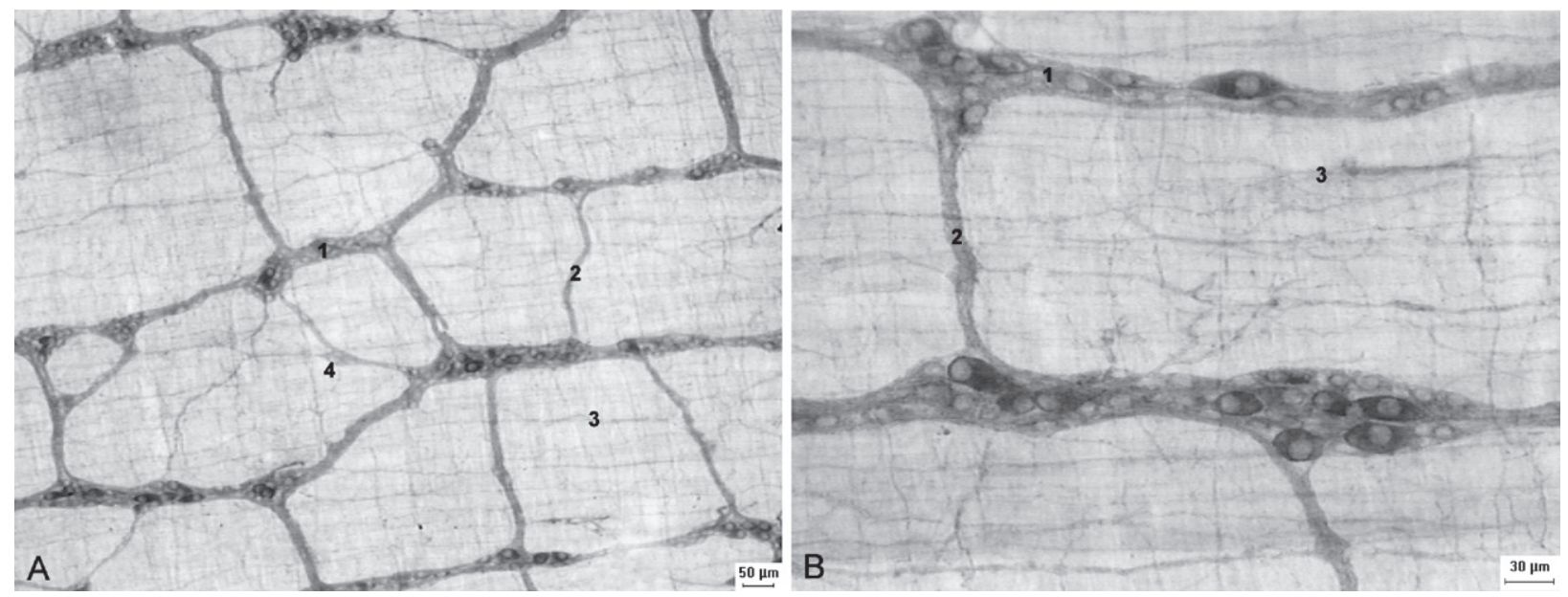

Figure 1 - Micrographs showing the components of the myenteric plexus of the ileum of rats stained by the myosin-V technique. Figure A e B: 1 - primary plexus; 2 - secondary plexus; 3 - tertiary plexus; 4 - isolated neurons. Calibration bar: (A) $50 \mu \mathrm{m}$ and (B) $30 \mu \mathrm{m}$.

evident. The nerve fibers of the secondary plexus are parallel to the muscular cells of the circular layer of the muscular tunica. The tertiary plexus was formed by fine nerve fibers, situated between the spaces left by the primary plexus (Fig. 1). It was observed a different intensity in the neurons staining in the myenteric ganglions (Fig. 2).

There was a $36.72 \%$ and $36.33 \%$ reduction in the neuronal density in the ileum of animals of group UD when compared to the untreated normoglycaemic (UN) and the normoglycaemic treated with L-glutamine $(\mathrm{NG})$ respectively $(\mathrm{P}<$ $0.05)$. The neuronal density of animals of groups
DG4 and DG45 was similar to that observed in the untreated diabetics (UD) $(\mathrm{P}>0.05)$ ( Fig. 3).

The cell profile area of the myosin- $\mathrm{V}$ stainedneurons of animals of group UD was $4.6 \%$ larger when compared to the animals of group UN ( $\mathrm{P}>$ 0.05) (Table II). The L-glutamine supplementation (group DG4 and DG45) did not change these results, with means similar to those of animals to group UD ( $\mathrm{P}>0.05)$. Most neurons had cell profiles that varied from 101 to $400 \mu \mathrm{m}^{2}$. The proportion of neurons in this range for groups UN, NG, UD, DG4 and DG45 was of $82.2 \%, 89.6 \%, 84.4 \%, 92.2 \%$ and $88.4 \%$ respectively (Fig. 4 ). 

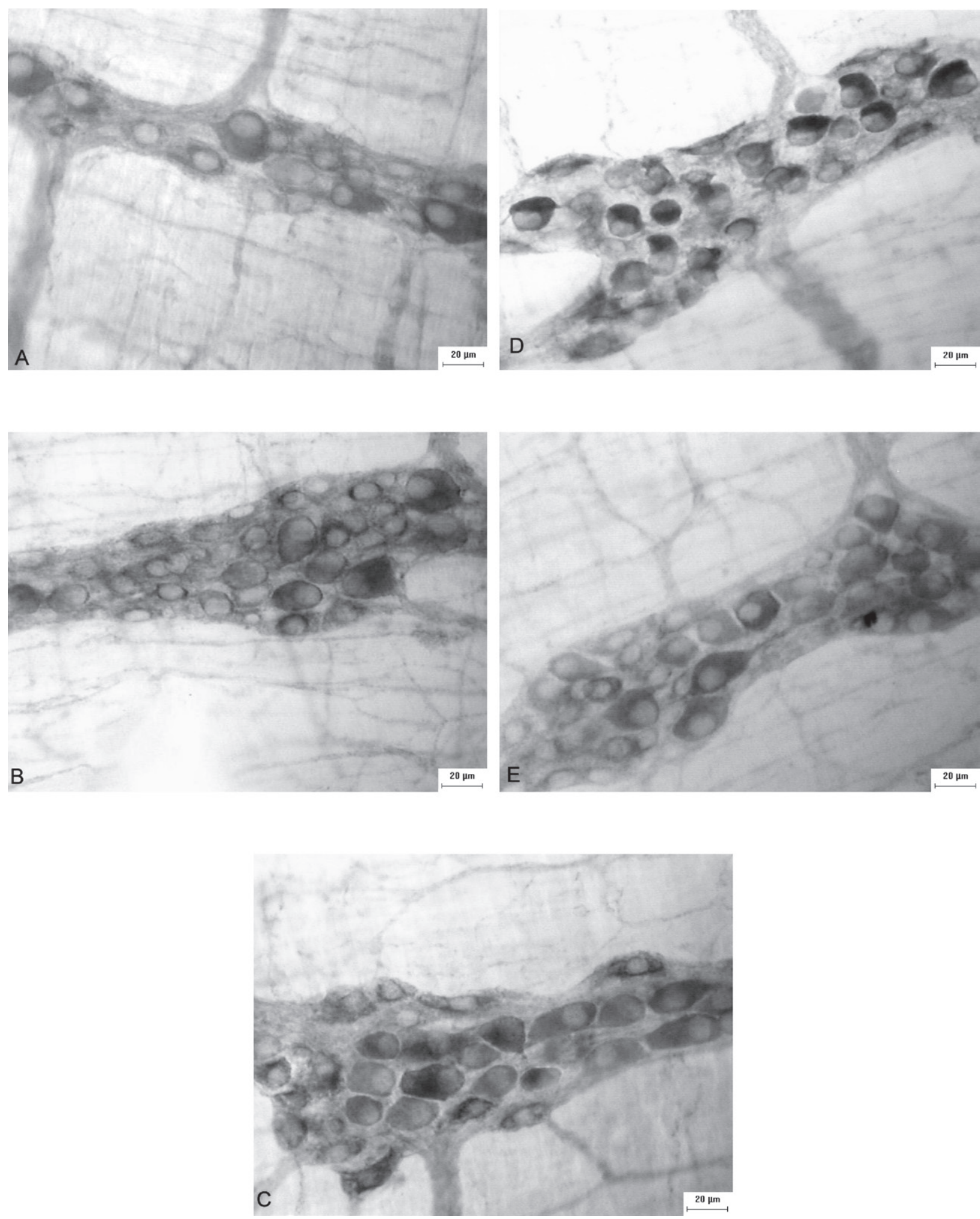

Figure 2 - Micrographs of the myenteric plexus of the ileum of rats showing myenteric ganglia stained by myosin-V belonging to animals from the groups: untreated normoglycaemic (A), L-glutamine-treated normoglycaemic (B), untreated diabetic (C), L-glutamine-treated diabetic (D), L-glutamine-treated diabetic (E). Calibration bar: $20 \mu \mathrm{m}$ 
TABLE II

Means and standard errors of the cell body areas of myosin- $\mathrm{V}$ stained neurons in groups: untreated normoglycaemic (UN), glutamine-treated normoglycaemic (NG), untreated diabetic (UD), glutamine-treated diabetic (DG4), glutamine-treated diabetic (DG45). $\mathbf{n}=\mathbf{5}$ rats per group.

\begin{tabular}{c|c}
\hline Group & myosin-V \\
\hline UN & $273.5 \pm 17.17$ \\
\hline NG & $255.4 \pm 5.268$ \\
\hline UD & $286.6 \pm 11.59$ \\
\hline DG4 & $285.5 \pm 21.16$ \\
\hline DG45 & $274 \pm 12.91$ \\
\hline
\end{tabular}

Means did not have significant differences by the $t$ - test $(\mathrm{P}>0.05)$.

Metaphasic INDEX AND Estimation OF Goblet CELLS IN THE VILLUS

The data related to the metaphasic index (Table III). The methafasic index of group UD was $23.2 \%$ higher when compared to group UN $(\mathrm{P}>0.05)$. The treatment with L-glutamine (DG4 group) promotes a increase of $6.92 \%$ in metaphasic index in relation to the UD group $(\mathrm{P}>0.05)$. The number of goblet cells of animals of groups UD, DG4 and DG45 was similar to those of animals of group UN and NG (P $>0.05)$ (Table III).

TABLE III

Frequency of Goblet cells and metaphasic indexes of crypts of the ileum of rats belonging to groups in non-treated normoglycaemic rats (UN), L-glutamine-treated normoglycaemic (NG), nontreated diabetic (UD), L-glutamine-treated diabetic (DG4) and (DG45). All results were shown as means \pm standard error. $\mathbf{n}=\mathbf{5}$ rats per group.

\begin{tabular}{c|c|c}
\hline Grupo & Goblet Cells (\%) & Index Metaphasic (\%) \\
\hline UN & $15.63 \pm 0.441$ & $6.792 \pm 0.4207$ \\
\hline NG & $14.53 \pm 1.273$ & $8.326 \pm 0.7619$ \\
\hline UD & $15.54 \pm 0.955$ & $8.856 \pm 0.8805$ \\
\hline DG4 & $15.79 \pm 0.798$ & $8.843 \pm 0.5702$ \\
\hline DG45 & $14.87 \pm 0.733$ & $7.586 \pm 0.8120$ \\
\hline
\end{tabular}

There were no significant differences when the groups were compared by the test of Tukey $(\mathrm{P}>0.05)$.

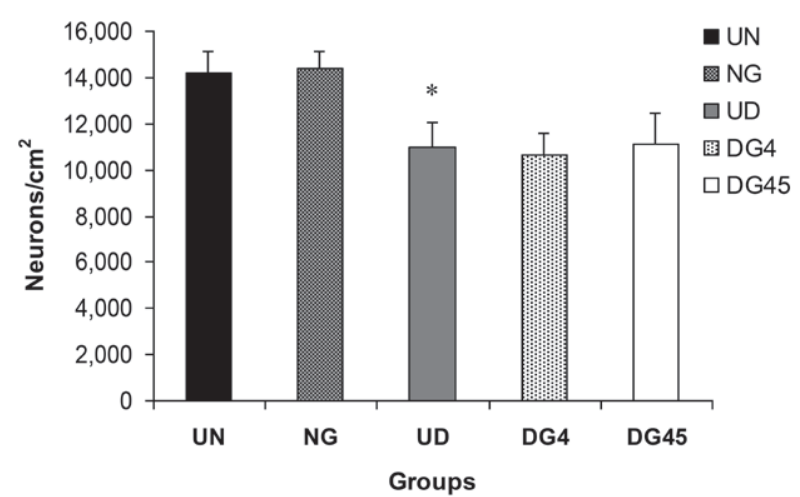

Figure 3 - Density (Neurons $/ \mathrm{cm}^{2}$ ) of myenteric neurons stained by myosin- $\mathrm{V}$ in the ileum of rats. Groups: untreated normoglycaemic (UN), glutamine-treated normoglycaemic (NG), untreated diabetic (UD), glutamine-treated diabetic (DG4), glutamine-treated diabetic (DG45). All results were shown as means \pm standard error. $\mathrm{n}=5$ rats per group. ${ }^{*} \mathrm{P}<$ 0.05 when compared to group $\mathrm{UN}$ and $\mathrm{NG}$.

\section{MORPHOMETRY OF VILLUS AND CRYPTS}

Villus height in rats from groups DG4 and DG45 were $45.5 \%(\mathrm{P}<0.05)$ and $32.4 \%(\mathrm{P}>0.05)$ higher than those in group UD, respectively. The crypts of animals of group UD had a depth similar to those evidenced in the animals of group UN (P $>0.05)$. The crypt depth in DG4 and DG45 were $27.63 \%$ and $29.17 \%$ larger than in UD ( $P>0.05)$, respectively. The means of the villi height $(\mu \mathrm{m})$ and crypt depth ( $\mu \mathrm{m})$ (Fig. 5).

\section{DISCUSSION}

Our experimental model of diabetes was effective because there was an increase on the daily water consumption, food intake and glycaemia. The animals of groups UD, DG4 and DG45 had a smaller body weight when compared to the normoglycaemic animals (groups UN and NG).

Myenteric neurons: The myosin- $\mathrm{V}$ immunohistochemical technique was used to stain the myenteric neurons in the muscular layer whole mounts (Drengk et al. 2000). Several authors have used this technique to stain myenteric neurons in different areas of the gastrintestinal tract (Buttow et al. 2003, 2004, Zanoni et al. 2003, 2005, Schoffen 


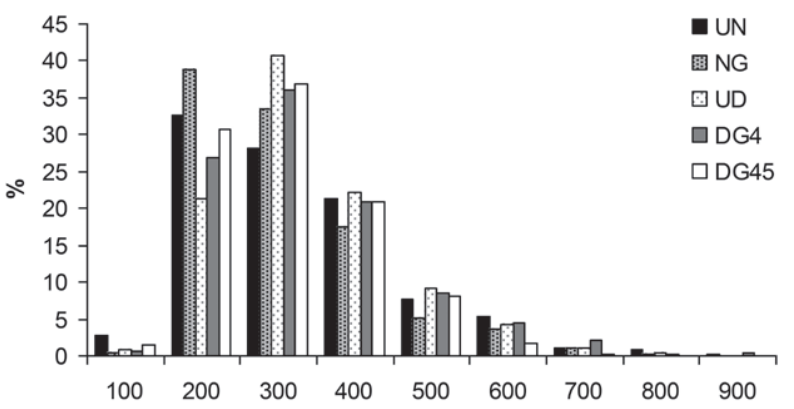

Figure 4 - Size distribution of myosin-V stained myenteric neurons. They were classified in classes of $100 \mu \mathrm{m}^{2}$ for the animals in the groups: untreated normoglycaemic (UN), glutamine-treated normoglycaemic (NG), untreated diabetic (UD), glutamine-treated diabetic (DG4), glutamine-treated diabetic (DG45). $\mathrm{n}=5$ rats per group.

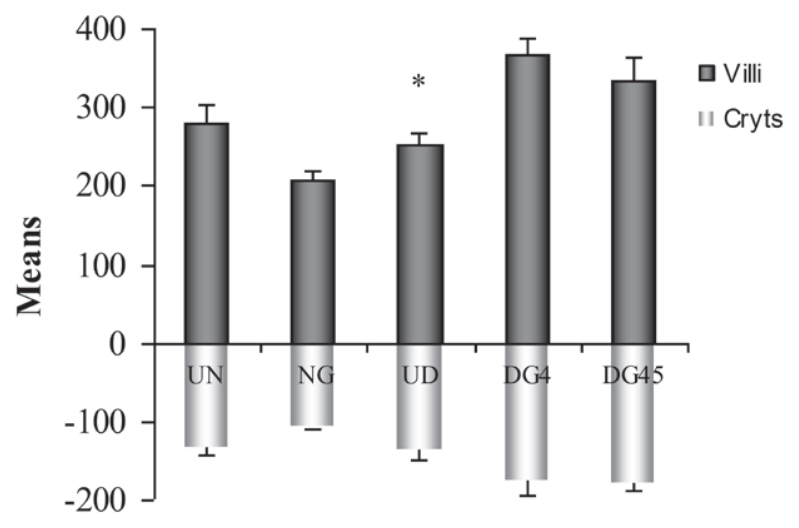

Groups

Figure 5 - Villi height $(\mu \mathrm{m})$ and crypts depth $(\mu \mathrm{m})$ in the ileum mucosa of untreated normoglycaemic rats (UN), L-glutaminetreated normoglycaemic (NG), untreated diabetic (UD), L-glutamine-treated diabetic (DG4) and (DG45). All results were shown as means \pm standard error. $\mathrm{n}=5$ rats per group. * $\mathrm{P}<0.05$ when compared to group UD.

et al. 2005). Myosin- $\mathrm{V}$ is a versatile motor protein and it is involved in the fast transport of vesicles from the dendrites to the axon (Langford 2002). This technique is used as marker of the overall neural population because the myosin- $\mathrm{V}$ is present in cell bodies and nerve fibers (Drengk et al. 2000). With this technique, we are able to observe the organization of the myenteric plexus. We verified the presence of the three components that compose this plexus (primary, secondary and tertiary) similar to previous studies Furness and Costa (1980). The variable intestinity of imunoreactivity in the myenteric neurons inside the ganglia was observed in all studied groups. According to Drengk et al. (2000) heterogeneity of intensity may indicate different levels of neuronal activity.

We observed a $36.72 \%$ decrease on density of myenteric neurons stained by the myosin- $\mathrm{V}$ in group UD when compared to the normoglycaemic (UN). This result was similar to the one found by Zanoni et al. (2003) and Alves et al. (2006) who verified a reduction in the neuron density in the ileum of diabetic rats. There are several factors that contribute to the reduction on the number of myenteric neurons. Some of them are: a) the increase of the aldose reductase activity, associated to an increase in the sorbitol and fructose levels (Ferraz et al. 1997); b) an increase in oxidative stress (Baynes 1991, Vincent et al. 2004) that causes an increment in the production of free radicals; c) a decrease in the levels of endogenous antioxidants. The glutathione levels are reduced during the hyperglycaemia leading to an increase in ROS (Parthiban et al. 1995, Greene et al. 1999, Vincent et al. 2004). Glutathione is an important antioxidant in most cells of mammals (Vincent et al. 2004). This substance serves as an essential cofactor for the glutathione peroxidase enzyme, which removes hydroperoxidase, and the formation of oxidized glutathione (GSSG). The reduced glutathione (GSH) is regenerated by the enzyme glutathione reductase using NADPH (Parthiban et al. 1995, Vincent et al. 2004). Therefore, the hyperactivity of the polyol pathway reduces the glutathione levels, causing an increase in the ROS (Nakamura 2002). This reduction is related to the increase of the aldose reductase activity that consumes NADPH, which is also necessary for the formation of the reduced glutathione (Tesfamariam 1994, Giugliano et al. 1996). All of these events involve an increase in oxidative stress and are related to the activation of a cascade of events that generate the apoptosis (Srinivasan et al. 2000, Barber 2003). 
We hypothesized that L-glutamine supplementation in the DG4 group of animals would prevent the development of diabetic neuropathy. Furthermore, the objective of L-glutamine supplementation of the DG45 group of animals was to work as a treatment for diabetic. However, the L-glutamine supplementation was not efficient either in preventing or in treating this pathology at the dose used. L-glutamine is a very important energy substratum for cells, being also a precursor for nucleotides, glutamate and, especially, the GSH synthesis. This amino acid has its concentration reduced during the catabolic stress (Vincent et al. 2004). Studies carried out by Roth et al. (2002) showed that rats fed with L-glutamine had an increase in their cellular content of GSH. We observed that L-glutamine supplementation (DG4 and DG45) did not avoid the decrease on the number of myenteric neurons. This might be due to the fact that several mechanisms were producing ROS. Among them are: the polyol pathway, the autoxidative glucosilation, the reduction of antioxidants and the reduction of the efficiency of the enzymatic system (Vincent et al. 2004). Therefore, a combined treatment of substances already studied individually (as the ascorbic acid [Zanoni et al. 2003] or acetil-1-carnitine [Miranda-Neto et al. 2005]) with L-glutamine could be effective, because ROS would be neutralized by different mechanisms. We speculate that another factor to be questioned would be in relation to the concentration of used L-glutamine. In this experiment a concentration of $1 \%$ was used and could have been too small to produce the wanted biological effect. We worked with this concentration, because there is evidence in the literature that higher concentrations $(4 \%)$ is harmful the intestinal mucous membrane (Shinozaki et al. 1997, Ameho et al. 1997). It is possible that an intermediate concentration could be beneficial to the neurons without damage to the intestinal mucous membrane.

There were no significant differences regarding the neuronal profile area when the five groups were compared. When comparing group UD with group UN, we observed that the immunoreactive neurons to myosin- $\mathrm{V}$ of animals belonging to UD were $4.6 \%$ larger than the animals from group UN. We have demonstrated previously Zanoni et al. (2003) that the cellular profile of myosin- $\mathrm{V}$ myenteric neurons of the ileum of diabetic rats was unaltered by treatment with ascorbic acid. On the other hand, we have also demonstrated that VIP-ergic and nitrergic neurons Zanoni et al. (2002, 2003 ) in the ileum had an increase in their area in diabetic rats and further, that ascorbic acid supplementation prevented this increase. We can infer that diabetes mellitus affects in a different way the subpopulations of myenteric neurons, since we have noticed no changes in the neuronal area when analyzing the neurons overall population and the suplementation with L-glutamine did not alter these results. When we analyze the distribution of the neuronal population in random classes at intervals of $100 \mu \mathrm{m}^{2}$, we verified that despite the size variability observed in the area of the neuronal profile (47.301 to $855.102 \mu \mathrm{m}^{2}$ ), most neurons in both groups had a profile cell area ranging from 101 to $400 \mu \mathrm{m}^{2}$. This shows the uniformity in the neuronal distribution between the groups.

Mucosa of the ileum: Our results did not show significant differences in the cell proliferation, crypts depth and villus height of the ileum mucosa at the end of $120^{\text {th }}$ experiment day in UD when compared to UN and NG. Several studies have already shown changes in the small intestine of non-supplemented diabetic rats such as hyperplasia, hypertrophy of the mucosa (Miller et al. 1977, Zhao et al. 2003), increase on the crypts depth and villus heights after 4 days of diabetes in the duodenum and 7 days of diabetes in jejunum and ileum (Zhao et al. 2003). These results differ due to their use of a model of acute diabetes mellitus while our experimental model is of chronic diabetes mellitus. It is likely that the intestinal mucosa underwent an adaptation to the chronic pathogenesis of the diabetes mellitus. Data observed by Zoubi et al. (1995) did not find 
morphometric changes in the crypts depth and villus height in the small intestine of rats after 84 days of the diabetes mellitus onset.

The intestinal mucous membrane of the animals of the group DG4 presented an increase in the cellular proliferation in the proportion of $6.92 \%$ and an increase in $45.5 \%$ in the height of the villus when compared to the group UD. The villus in groups DG45 was $32.4 \%$ higher than those in group UD. The crypt depth in groups DG4 and DG45 were larger when compared to group UD $(27.63 \%$ and $29.17 \%$ respectively). These results can be related the functional activity of L-glutamine which is considered the main energy source for the enterocytes (Fleming et al. 1997) to promote proliferation and cellular migration of the intestinal mucosa cells (Ruemmele et al. 1999). L-glutamine links to receptors at the luminal or basolateral surface of enterocytes and causes its own absorption (Palanch 2000). It is also possible that the villus suffered a delay in its cell death process, the L-glutamine may have prevented the villus apoptosis from happening because glutamine is a precursor of glutathione, which is reduced in intestinal mucosa due to the diabetes mellitus (Bhor et al. 2004). Previous studies have demonstrated that rats supplemented with L-glutamine (3\%), for a period of 8 days, had an increased on the height of villus and number of mitotic cells per crypt after treatment with chemotherapeutics (Klimberg et al. 1990).

The number of goblet cells counts was similar among groups UD, UN, NG. A morphological study of the enteric epithelial mucosa of streptozotocin-induced diabetic rats, with 14 days of age has demonstrated similar number of goblet cells in the jejunum, ileum and duodenum Etharh and Carr (1997) or just ileum Mantle et al. (1989) when comparing the diabetic and control groups. In the present study, L-glutamine supplementation (groups DG4 and DG45) did not alter the number of goblet cells counts in the villus.
Summing up, the present work showed that the L-glutamine supplementation (1\%) was not effective in altering the diabetes-induced loss of myenteric neurons, but promoted an increase of the size of the villus and depth of the crypts in the animals of the group DG4 and DG45. These results allow us to suggest that it is necessary new researches to prove the effectiveness of the suplementation with L-glutamine on the innervation enteric of the ileum of diabetic rats.

\section{ACKNOWLEGMENTS}

The authors would like to thank the support of Maria Euride do Carmo Cancino, Maria dos Anjos Fortunato, Valdir Trombeli and José Antonio de Souza for their excellent technical support.

\section{RESUMO}

O objetivo deste estudo foi investigar o efeito da suplementação com L-glutamina para prevenir as alterações induzidas pelo diabetes sobre os neurônios mientéricos e também verificar o efeito sobre a mucosa do íleo de ratos Wistar. Os animais foram divididos em cinco grupos (n =5): normoglicêmico não tratado (UN), normoglicêmico tratado com L-glutamina ( $\mathrm{NG})$, diabético não tratado (UD), diabético tratado com L-glutamina, iniciando no $4^{\circ}$ (DG4) ou $45^{\circ}$ (DG45) dias após a indução do diabetes. O aminoácido foi adicionado à dieta a $1 \%$. A densidade e o tamanho dos neurônios, o índice metafásico nas criptas, a altura das vilosidades, a profundidade das criptas e o número de células caliciformes foram determinados. Não houve diferença na densidade neuronal e na área do corpo celular dos neurónios mientéricos miosina- $\mathrm{V}$ imunomarcados dos grupos DG4 e DG45 quando comparados com o grupo D. O índice metafásico e o número de células caliciformes não apresentaram diferenças significativas quando todos os grupos foram comparados $(\mathrm{P}>0,05)$. A altura das vilosidades dos grupos DG4 e DG45 foi 45,5\% (P < 0,05) e 32,4\% (P $>0,05)$ superior que no grupo UD, respectivamente. As criptas analisadas apresentaram profundidade semelhante para todos os grupos estudados. 
Palavras-chave: diabetes mellitus, L-glutamina, plexo mioentérico, miosina- $\mathrm{V}$, ratos.

\section{REFERENCES}

AfZAAL SM AND SALEEM I. 2002. Aetipathogenesis and management of diabetic neuropathy. J Assoc Physicians India 50: 707-711.

Alves AM, Alves EP, Fregonesi CET, Defani MA, Stabille SR, Evangelista CEB, SANTOS CA AND Miranda NETO MH. 2006. Morphoquantitative Aspects of NADHDiaphorase Myenteric Neurons in the Ileum of Diabetic Rats Treated with Acetyl-1-Carnitine. Anat Histol Embryol 35: $13-18$

AMEHO CK, AdJEI AA, HARRISON EK, TAKESHITA K, MORIOKA T, ARAKAKI Y, ITO E, SUZUKI I, KULKARNI DA AND YAMMOTO S. 1997. Prophylactic effect of dietary glutamine supplementation on interleukin 8 and tumor necrosis factor a production in trinitrobenzenesulfonic acid induced colitis. Gut 41: 487-493.

AMORES-SÁNCHEZ MI AND MEdINA MA. 1999. Glutamine, as a precursor of glutathione, and oxidative stress. Mol Genet Metab 67: 100-105.

BARBER AJ. 2003. A new view of diabetic retinopathy: a neurodegenerative disease of the eye. Prog Neuropsychopharmacol Biol Psychiatry 27: 283-290.

BAYNES JW. 1991. Role of oxidative stress in development of complications in diabetes. Diabetes 40: 405-412.

BELAI A AND BURNSTOCK G. 1990. Changes in adrenergic and peptidergic nerves in the submucous plexus of streptozocin-diabetic rat ileum. Gastroenterology 98: $1427-1436$

Belai A, Lefebvre RA And Burnstock G. 1991. Motor activity and neurotransmitter release in the gastric fundus of streptozotocin-diabetic rats. Eur J Pharmacol 194: 225234.

Belai AJ, Lincoln PM And Burnstock G. 1988. Progressive changes in a adrenergic, serotonergic, and peptidergic nerves in proximal colon of streptozotocin-diabetic rats. Gastroenterology 95: 1234-1241.

Bergmeyer HU AND BeRnet E. 1974. Determination of glucose with glucose oxidase and peroxidase. Methods of enzymatic analysis. Verlag Chemiem Academic Press, p. 87-89.

BHOR VM, RAGHURAM N AND SIVAKAMI S. 2004. Oxidative damage and altered antioxidant enzyme activities in the small intestine of streptozotocin-induced diabetic rats. Int J Biochem Cell Biol 36: 89-97.

Buttow NC, Santin M, Macedo LC, Teixeira ACN, Novakowski GC, Bolonheis ATR AND Assmann K. 2004. Study of the myenteric and submucous plexuses after BAC treatment in the intestine of rats. Biocell 28: 135-142.

Buttow NC, Zucoloto S, Espreafico EM, GAMA P AND ÁlvARES EP. 2003. Substance P enhances neuronal area and epithelial cell proliferation after colon denervation in rats. Dig Dis Sci 48: 2069-2076.
DRENGK AC, KaJIWARA JK, GARCIA SB, CARMO VS, LARSON RE, ZUCOLOTO S AND ESPREAFICO EM. 2000. Imunolocalisation of myosin- $\mathrm{V}$ in the enteric nervous system of the rat. J Auton Nerv Syst 78: 109-112.

ETTARH RR AND CARR KE. 1997. A morphological study of the enteric mucosal epithelium in the streptozotocindiabetic mouse. Life Sci 61: 1851-1858.

FERraz ME, IWAMOTO I, BATISTA MR, BRUNALDI RB AND BAZOTTE RB. 1997. Sorbitol accumulation in rats kept on diabetic condition for short and prolonged periods. Acta Pharmacol Sin 18: 309-311.

FLEMING SE, ZANBelL KL AND Fith MD. 1997. Glucose and glutamine provide similar proportions of energy to mucosal cells of rat small intestine. Am J Physiol 273: 968-978.

Furness JB AND Costa M. 1980. Types of nerves in the enteric nervous system. Neuroscience 5: 1-20.

Giugliano D, Ceriello A And PaOlisso G. 1996. Oxidative stress and diabetic vascular complication. Diabetes Care 19: 257-267.

Greene DA, Stevens MJ, Obrosova I AND Feldman EL. 1999. Glucose-induced oxidative stress and programmed cell death in diabetic neuropathy. Eur J Pharmacol 375: 217-223.

Hernandes L, Pereira LCMS AND Álvares EP. 2003. Goblet cell number in the ileum of rats denervated during suckling and weaning. Biocell 27: 347-351.

Klimberg VS, SAlloum RM, Kasper M, Plumley DA, DOLSON DJ AND HAUTAMAKI RD. 1990. Oral glutamine accelerates healing of the small intestine and improves outcome after whole abdominal radiation. Arch Surg 125: 1040-1045.

KuYvenhoven JP AND MeINDERS AE. 1999. Oxidative stress and diabetes mellitus pathogenesis of long-term complications. Eur J Inter Med 10: 9-19.

LANGFORD MG. 2002. Myosin-V a Versatile Motor for ShortRange Vesicle Transport. Traffic 3: 859-865.

Mantle M, Thakore E, AtKins E, Mathison R AND DAVISON JS. 1989. Effects of streptozotocin-diabetes on rat intestinal mucin and goblet cells. Gastroenterology 97: 68-75.

Miller DL, Hanson W, Schedl HP ANd Osborne JW. 1977. Proliferation rate and transit time of mucosal cells in small intestine of the diabetic rat. Gastroenterology 73: 13261332.

Miranda Neto MH, Defani MA, Fregonesi CEPT, NATALi MRM AND PEREIRA A. 2005. Morphometric and Quantitative Evaluation of the NADH-diaphorase Positive Myenteric Neurons of the Jejunum of streptozotocinDiabetic Rats Supplemented with Acetyl-L-Carnitine. Anat Histol Embryol 34: 154-158.

NAKAMURA J. 2002. Transition metals and polyol pathway in the development of diabetic neuropathy in rats. Diabetes Metab Res Rev 18: 395-402.

PALANCH AC. 2000. Metabolismo da glutamina no intestino. In: CURI R (Ed), Glutamina metabolismo e aplicações clínicas e no esporte, Rio de Janeiro: Sprint, p. 85-96. 
PARTHIBAN A, VIJAYALINGAM S, SHANMUGASUNDARAM KR AND MOHAN R. 1995. Oxidative stress and the development of diabetic complications-antioxidants and lipid peroxidation in erythrocytes and cell membrane. Cell Biol Int 19: 987-993.

Roth E, Koehler R, Manhart N, Exner R, Wessener B, STRASSER E AND SPITTLER A. 2002. Regulative potential of glutamine-relation to glutathione metabolism. Nutrition 18: $217-221$

RUEMMELE FM, RUEMMELE C, LEVY E AND SEIDMAN E. 1999. Les mécanismes moléculaires de la regulation du renouvellement de cellules epithéliales intestinales par des nutriments. Gastroenterol Clin Biol 23: 47-55.

SCHOFFEN JPF, SOARES A, FREITAS P, BUTTOW NC AND NATALI MRM. 2005. Effects of a hypoproteic diet on myosin-V immunostaneid myenteric neurons and the proximal colon wall of aging rats. Auton Neurosci 122: 77-83.

ShINOZAKI M, SAITO H AND MUTO T. 1997. Excess glutamine exacerbates trinitrobenzenesulfonic acid - induced colitis in rats. Dis Colon Rectum 40: 59-63.

SRINIVASAN S, STEVEnS M AND WILEY JW. 2000. Diabetic peripheral neuropathy: evidence for apoptosis and associated mitochondrial dysfunction. Diabetes 49: 19321938.

TESFAMARIAM B. 1994. Free radicals in diabetes endothelial cell dysfunction. Free Radic Biol Med 16: 383-391.

VAHDAT L. 2001. Reduction of paclitaxel-induced peripheral neuropathy with glutamine. Clin Cancer Res 7: 11921197.

VInCENT AM, Russell JW, Low P AND FELDMAN EL. 2004. Oxidative stress in the pathogenesis of diabetic neuropathy. Endocr Rev 25: 612-628.

VINIK AI. 1999. Diabetic Neuropathy: Pathogenesis and therapy. Am J Méd 107: 17-26.

VINIK AI AND MEHRABYAn A. 2004. Diabetic neuropathies. Med Clin N Am 88: 947-999.

Vinson JA, Staretz MA, Bose P AND Kassm HM. 1989. In vitro and in vivo redution of erythrocyte sorbitol by ascorbic acid. Diabetes 38: 1036-1041.
WATFORD M, SMith EM AND ERBELding EJ. 1984. The regulation of phosphate-activated glutaminase activity and glutamine metabolism in the streptozotocin-diabetic rat. Biochem J 224: 207-214.

WOLFGAND CL, LIN C, MENG Q, KarinCH AM AND VARY TC. 2003. Pan $M$ growth factor activation of intestinal glutamine transport is mediated by mitogen - activated protein kinases. J Gastrointest Surg 7: 149-156.

ZANONI JN, BUtTOW NC, BAZOTTE RB AND MiRANDANETO MH. 2003. Evaluation of the population of NADPHdiaphorase-stained and myosin- $\mathrm{V}$ myenteric neurons in the ileum of chronically streptozotocin-diabetic rats treated with ascorbic acid. Auton Neurosci 104: 32-38.

ZANONI JN, DE FreITAS P, PEREIRA RVF, DOS SANTOS Pereira MA AND Miranda-Neto MH. 2005. Effects of supplementation with ascorbic acid for a period of 120 days on the myosin-v and NADPH-d positive myenteric neurons of the ileum of rats. Anat Histol Embryol 34: 149-153.

ZANONI JN, HERNANDEZ L, BAZOTTE RB AND MIRANDA-NETO MH. 2002. Terminal ileum submucous plexus: a study of the VIP-agric neurons of diabetic rats treated with ascorbic acid. Arq Neuropsiquiatr 60: 32-37.

ZANONI JN, Miranda-Neto MH, BazotTe RB AND SouZA RR. 1997. Morphological and quantitative analysis of the neurons of the myenteric plexus of the cecum of streptozotocin diabetic rats. Arq Neuropsiquiatr 55: 696-702.

ZHAO J, YANG J AND GREGERSEN H. 2003. Biomechanical and morphometric intestinal remodelling during experimental diabetes in rats. Diabetologia 46: 1688-1697.

ZOUBI SA, WILLIAMS MD, MAYHEW TM AND SPARROW RA. 1995. Number and ultrastructure of epithelial cells in crypts and villus along the streptozotocin-diabetic small intestine, a quantitative study on the effects of insulin and aldose reductase inhibition. Virchows Archiv 427: 187-193. 